\title{
INTERRELATION AMONG PRECIPITATION AND ELEMENT- CONTENT OF GRAPE VITIS VINIFERA L. CV. KÉKFRANKOS, GROWN IN DIFFERENT TERROIRS
}

\author{
Richárd Nagy ${ }^{*}$, Szilárd Szabó ${ }^{2}$, Attila Kerényi ${ }^{3}$ \\ \& Borbála Bálo 4
}

${ }^{1}$ Eszterházy Károly University, Innoregion Knowledge Centre, H-3300 Eger, Leányka str. 6; ${ }^{2}$ Department of Physical Geography and Geoinformatics, University of Debrecen, H-4032 Debrecen, Egyetem Sq. 1.; ${ }^{3}$ Department of Landscape Protection and Environmental Geography, University of Debrecen, 4032 Debrecen, Egyetem Sq. 1.; 4 Department of Viticulture, Szent István University; *E-mail: nagy.richard@uni-eszterhazy.hu

\begin{abstract}
Total nutrient content of soils and quantity of potentially available part in plants are determined in this study. Main affecting factors of nutrient uptake might be the geochemical conditions of soils and the applied agro-technological methods, while the real uptake of plants can be influenced by precipitation and evaporation conditions beside the rootstock and the used grafted scions. The element content of grape berries of Vitis vinifera $L$. Kékfrankos cultivar was studied in identical rootstocks and scions at different production areas in Northern Hungary, during two consecutive years with somehow contrasting natural precipitation. Significant effect of the precipitation was found on the elements-uptake by the plants in general. Furthermore, it was also found, that the role of production area becomes increasingly important in grape production and quality, as well. Higher precipitation resulting greater elemental content and variability in comparison with the drier years.
\end{abstract}

Keywords: climate, grapevine, precipitation, trace element

\section{INTRODUCTION}

The climatic conditions of a production area are determined as macro-, meso- and micro-climate. While macro-climate determines temperature and precipitation conditions at a regional scale, mesoclimate varies according to local topographic conditions (Gladstones 1992). According to Hunter, Bonnardot (2011), climate has the main role in physiological processes of grapevine and thus 
determining the chemical composition of leaves and berries, the colour of the berries and the date of ripening, etc. Drappier et al. (2017) pointed out that the composition and character of wine from the vineyards around Bordeaux changes with climatic change. Bartholy, Pongrácz (2010) proved that the frequency of extreme precipitation increased in the Carpathian Basin in the second half of the $20^{\text {th }}$ century while annual precipitation slightly decreased. On the basis of climatic models, they consider that the climate of the region becomes drier at summers and wetter at winters in the $21^{\text {st }}$ century.

The quantity of micro- and macro-elements in the soil are influenced not only by the soil forming processes and geological conditions but by dry and wet deposition from the atmosphere as well. The latter is especially significant in urban environments (Soriano et al. 2012), therefore, the monitoring of micro- and macro-elements in soils and plants and studying their uptake are important.

Webb et al. (1995) studied the amount of cations regarding the relationship between soil and must and divided them into two groups. Cations belonging to the first group are accumulated in grapes, of exceeding even the concentration values, found in the soils. This group includes $\mathrm{K}, \mathrm{Na}, \mathrm{Mn}, \mathrm{Pb}, \mathrm{Cu}$. Cations of the second group appear in the pressed must of the grapes in smaller quantity than in the soil. This group includes $\mathrm{Ca}, \mathrm{Sr}, \mathrm{Zn}$. As a conclusion of detailed studies Bramley et al. (2011) stated that the quantity of the mineral components in the must is only in loose correlation with the pedological and geochemical conditions of the production area. Pepi et al. (2016) established a correlation between the rare earth elements (REE) concentration in the berries and REEs available fraction in the soil; which allowed the discrimination between the different origins of grapes.

Based on the relationship between soil $\mathrm{pH}$ and the uptake of nutrients, Candolfi-Vasconcelos et al. (1997) found significant differences among production areas with different soil conditions. Such concept of considering soil quality was supported by Bálo et al. (2010), and Biró (2015). Numerous vine studies and viticultural research (Swinchatt 2006; Coipel et al. 2006) studied the elemental transport in bed rock - soil type - grapevine - wine, however, with very varying results. No direct correlation was detected in the uptake of the different macro-, meso- and micro-elements and the 
various environmental factors. Results can be classified into two groups. Some scientists are highlighting the importance of the rootstocks in element-composition, while others are showing the necessity of proper water supply. Numerous studies focused on the joint effects of the two factors. Regarding the nutrient uptake Kocsis et al. (2001) associates the greatest effect with rootstockscion relationship, showing also that dry conditions strongly influence element uptake compared to normal, wetter vintage years. In dry years, the potassium content of the grape must show lower values and the effect of the rootstocks are also considered (Brancadoro et al. 1995). According to Cus (2004), climatic and soil conditions can modify the properties of the rootstock and scion specifics, therefore, their effects could be different by vintage and production area.

Among factors determining water supply, vintage and the water budget conditions of the soil worth mentioning as these together influence the uptake of nutrients of plants in relation to the stress tolerance of the rootstock. Water supply is influenced by slope and soil conditions apart from precipitation. Andres de Prado et al. (2007) studied the chemical composition of wines in the case of soils having different water budget conditions. Beside those parameters, the extreme drought conditions had significant effect also on the characteristics of the wines.

Objective of the present study was to compare different wine grape production sites and the effect of annual variability of natural precipitation regarding some of the elements, taken up by grape fruits.

\section{MATERIAL AND METHODS}

The present research was carried out on 9 study plots in the area of the Eger wine region in the north-eastern part of Hungary (Table 1). Examinations were performed on Vitis vinifera L. Kékfrankos grapevine cultivar grafted on Berlandieri x Riparia, T.5.C. rootstock with vertical shoot positioning (VSP). 
NAGY et al. (2018): Interrelation among precipitation and element-content in different terroirs

Table 1. Main characteristics of plantations in the study areas.

\begin{tabular}{|c|c|c|c|c|}
\hline Vineyards & $\begin{array}{c}\text { GPS } \\
\text { Coordinates }\end{array}$ & $\begin{array}{l}\text { Row and vine } \\
\text { distance }\end{array}$ & $\begin{array}{c}\text { Training } \\
\text { system }\end{array}$ & $\begin{array}{c}\text { Year of } \\
\text { planting }\end{array}$ \\
\hline Kölyuktetó - KT & $\begin{array}{c}\text { N47.864; } \\
\text { E20.383 }\end{array}$ & $3.00 \times 1.20 \mathrm{~m}$ & Umbrella & 1993 \\
\hline $\begin{array}{l}\text { Nagy-Eged-dúló́ } \\
\text { lower - NEA }\end{array}$ & $\begin{array}{l}\text { N47.920; } \\
\text { E20.420 }\end{array}$ & $3.00 \times 1.00 \mathrm{~m}$ & Umbrella & 1988 \\
\hline $\begin{array}{c}\text { Nagy-Eged-dülö } \\
\text { upper - NEK }\end{array}$ & $\begin{array}{l}\text { N47.922; } \\
\text { E20.418 }\end{array}$ & $3.00 \times 1.00 \mathrm{~m}$ & Umbrella & 1988 \\
\hline Síkhegy-SH & $\begin{array}{l}\text { N47.916; } \\
\text { E20.431 }\end{array}$ & $3.00 \times 1.00 \mathrm{~m}$ & Umbrella & 1989 \\
\hline Vidra-VD & $\begin{array}{l}\text { N47.907; } \\
\text { E20.419 }\end{array}$ & $3.00 \times 1.00 \mathrm{~m}$ & Guyot & 1988 \\
\hline $\begin{array}{c}\text { Juhszalagos - } \\
\text { JSZ }\end{array}$ & $\begin{array}{l}\text { N47.867; } \\
\text { E20.483 }\end{array}$ & $3.00 \times 1.00 \mathrm{~m}$ & Guyot & 1995 \\
\hline Szérúhely-SZH & $\begin{array}{l}\text { N47.885; } \\
\text { E20.496 }\end{array}$ & $3.00 \times 1.00 \mathrm{~m}$ & Umbrella & 1995 \\
\hline Tó-bérc-TB & $\begin{array}{l}\text { N47.872; } \\
\text { E20.289 }\end{array}$ & $3.00 \times 1.00 \mathrm{~m}$ & $\begin{array}{l}\text { Medium high } \\
\text { cordon }\end{array}$ & 1998 \\
\hline $\begin{array}{l}\text { Nagy- } \\
\text { galagonyás }-N G\end{array}$ & $\begin{array}{l}\text { N47.867; } \\
\text { E20.365 }\end{array}$ & $3.00 \times 1.00 \mathrm{~m}$ & Umbrella & 1985 \\
\hline
\end{tabular}

The amount of precipitation was recorded by using a BES-06 tipping bucket rain gauge developed by Boreas Ltd. (www.boreas.hu) in automated meteorological stations operating during 7 study areas with the accuracy of $0.1 \mathrm{~mm}$.

Fruit samples of grapes were all taken on the same day in the ripening season directly before harvesting in the different plots. Sampling was performed on the 3rd of October in 2010 and on the 24th September in 2011 due to differences in ripening. Sampling was performed on the basis of the random walk method. Samples were taken from bunches of various sizes at different heights from both sides of a given wine row. From various parts of bunches around 100 berries were taken from each plot. Samples were washed in distilled water after sampling and then dried in desiccators at $80^{\circ} \mathrm{C}$. Finally, grapes were homogenized by using porcelain mortars. Destruction and exposition was made by using 5 ml cc. $\mathrm{HNO}_{3}$ and $2 \mathrm{ml} \mathrm{H}_{2} \mathrm{O}_{2}$ (VWR, Hungary Ltd). The substrates were filtered via $228 \mathrm{~nm}$ filter-paper and diluted to $30 \mathrm{ml}$. A Perkin-Elmer 3000 FAAS device was used for destruction and elemental analyses were performed using an ICP-OES device. 


\section{RESULTS AND DISCUSSION}

\section{The relationship between precipitation and element uptake in different vintages}

Automated meteorological stations were placed into 7 production areas out of the 9 plots (Kőlyuktető, Sík-hegy, Tó-bérc, Szérűhely, Juhszalagos, Nagy-Eged-dűlő lower and upper). The amount of precipitation in 2010 was 2-3 times higher than in 2011 (Figure 1).

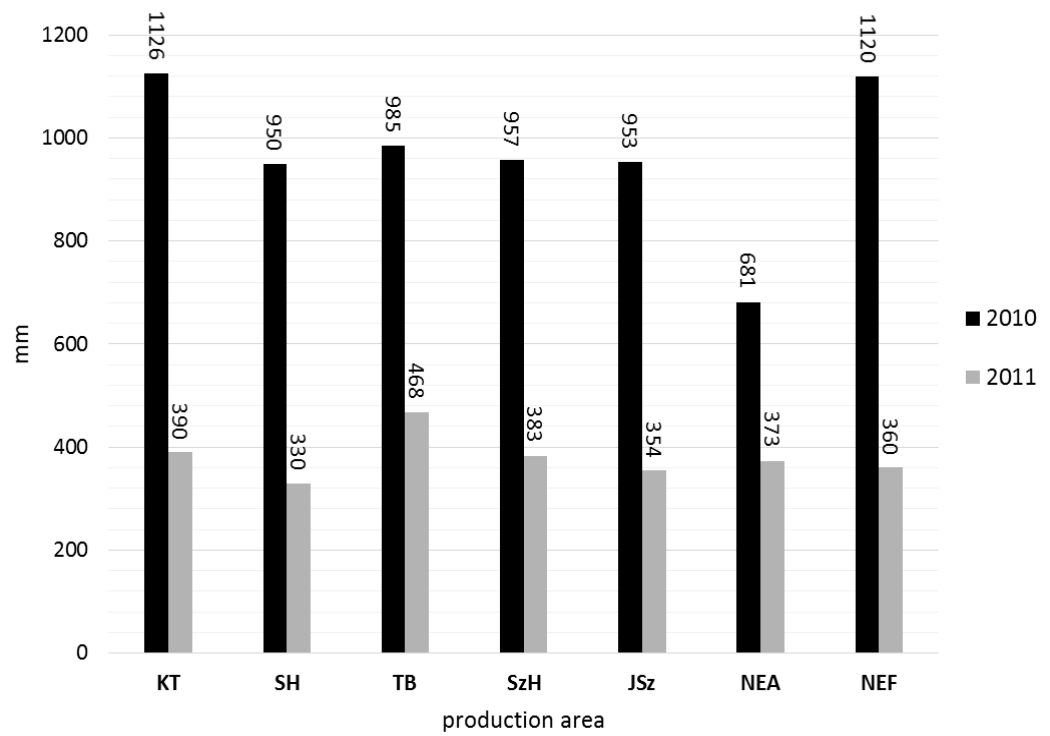

Figure 1. Amount of annual rainfall for 2010 and 2011 at production areas of grapes, assessed by meteorological stations ( $\mathrm{mm})$. Further details in text.

Since the amount of precipitation might significantly influences the element uptake of plants, the elemental content of grape samples from the two years were compared.

No significant differences were detected between the two vintages in the case of certain elements like $\mathrm{Ba}, \mathrm{Mn}$ and $\mathrm{Ni}$. In contrast, $\mathrm{Al}, \mathrm{Ca}, \mathrm{Fe}, \mathrm{K}, \mathrm{Mg}, \mathrm{Na}, \mathrm{Zn}$ were present in grapes in a significantly larger quantity in the vintage of 2010. This can be explained by an intensified sap flow in the plants driven by the greater amount of precipitation. As a result, higher amount of elements enter the plant and thus they appear in the berries in higher quantity as well. $\mathrm{Cu}, \mathrm{Cr}, \mathrm{Pb}$, however, were present in the 
berries in significantly greater quantity in the vintage of the drier year, 2011 (Figure 2, Table 2). This can be explained with the fact, that all three elements were deposited from the atmosphere in the greatest quantity. This means mostly spraying in the case of copper which was deposited on the surface of grapes in large quantities (Weng et al. 2003). It can be washed from the berry surface moderately with rain, therefore in drier years it is present in significant amounts on the berry skin (Brun et al. 1998; Deluisa et al. 1996). The quantity of copper measured among the grape samples depends mostly on the type of chemicals used in the course of spraying, on the number of sprayings and on the time passed from the last spraying, till the date of sampling and this was not observed in the present study. Cr appear in the atmosphere as aerosols settling onto the surface of the Earth with either wet or dry deposition. Following dry deposition rain washes it into the soil from the leaves and different plant parts and this explains why it was found in smaller quantity in the sample from 2010 when the amount of precipitation was greater. $\mathrm{Pb}$ in the soil can be hardly taken up by plants thus atmospheric deposition has the most important role (Alloway 2012). Pb gets onto the surface of the Earth by dry deposition thus in drier years, it appears on the surface of plants and of grape bunches in greater quantities, that are not washed away by precipitation.

Table 2. Differences of certain elements between vintages from 2010 and 2011 (Mann-Whitney test; bold letters: $\mathrm{p}<0.05$ ).

\begin{tabular}{cccccccc}
\hline & $\mathbf{A l}$ & $\mathbf{B a}$ & $\mathbf{C a}$ & $\mathbf{C r}$ & $\mathbf{C u}$ & $\mathbf{F e}$ & $\mathbf{K}$ \\
\hline $\begin{array}{c}\text { Mann- } \\
\text { Whitney U }\end{array}$ & .000 & 54.500 & 8.000 & 24.500 & 10.000 & 30.000 & 30.000 \\
\hline $\mathbf{Z}$ & -4.157 & -1.011 & -3.695 & -2.773 & -3.580 & -2.425 & -2.425 \\
\hline $\begin{array}{c}\text { Asymp. Sig. } \\
\text { (2-tailed) }\end{array}$ & $\mathbf{. 0 0 0}$ & .312 & $\mathbf{. 0 0 0}$ & $\mathbf{. 0 0 6}$ & $\mathbf{. 0 0 0}$ & $\mathbf{. 0 1 5}$ & $\mathbf{. 0 1 5}$ \\
\hline & $\mathbf{M g}$ & $\mathbf{M n}$ & $\mathbf{N a}$ & $\mathbf{N i}$ & $\mathbf{P b}$ & $\mathbf{Z n}$ \\
\hline $\begin{array}{c}\text { Mann- } \\
\text { Whitney U }\end{array}$ & 8.000 & 55.500 & .000 & 60.500 & .000 & 18.000 \\
\hline $\mathbf{Z}$ & -3.695 & -.953 & -4.157 & -.666 & -4.158 & -3.119 \\
\hline $\begin{array}{c}\text { Asymp. Sig. } \\
\text { (2-tailed) }\end{array}$ & $\mathbf{. 0 0 0}$ & .341 & $\mathbf{. 0 0 0}$ & .506 & $\mathbf{. 0 0 0}$ & $\mathbf{. 0 0 2}$ \\
\hline
\end{tabular}



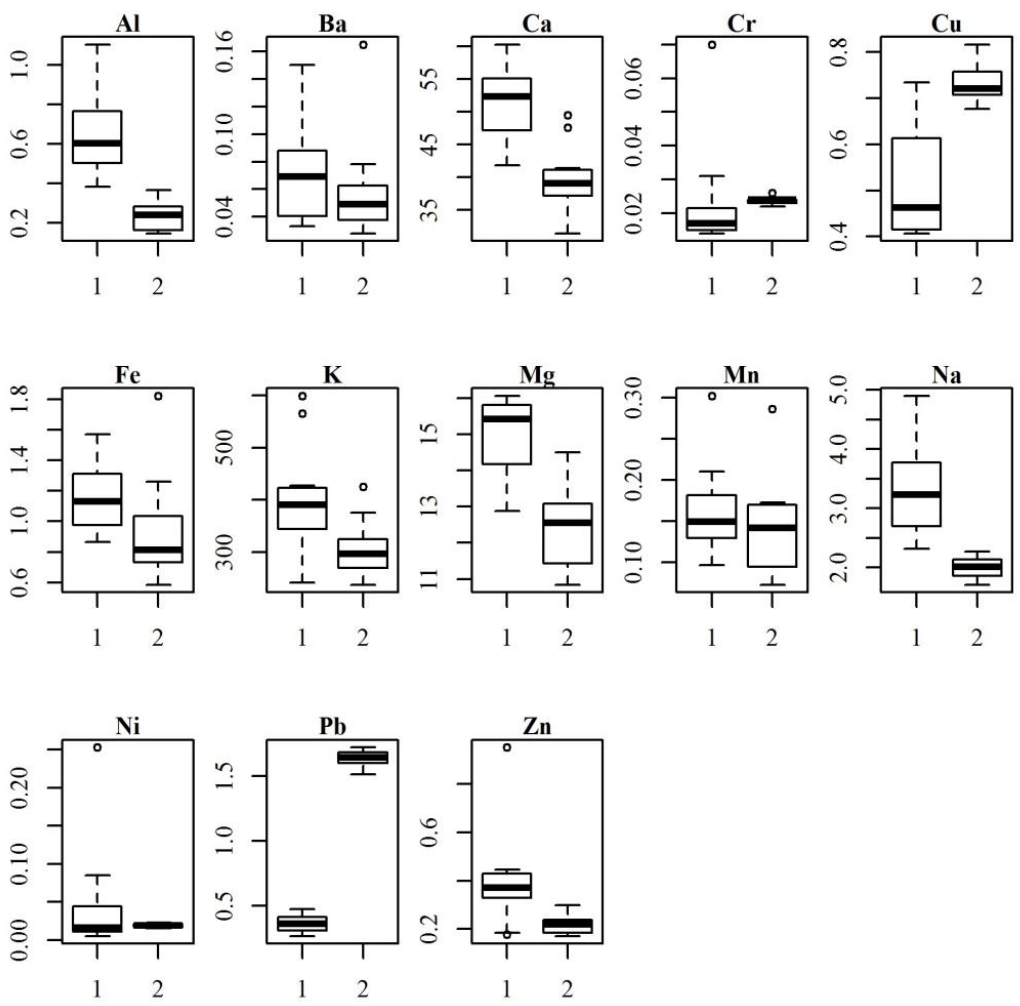

Figure 2. Statistical parameters of the elemental content of berries from vintages of 2010 (1) and 2011 (2) (minimum, maximum, median, lower quartile, upper quartile) as the average of the studied nine area.

Studying the elemental composition of the berry samples of the two years significant differences were found not only in the average quantity of individual elements and in the minimum and maximum values, but also in the standard deviation of the values (Tables 3 and 4). In the wet year of 2010 the standard deviation of values was higher in the case of $\mathrm{Al}, \mathrm{Ba}, \mathrm{Ca}, \mathrm{Cr}, \mathrm{Cu}, \mathrm{Fe}, \mathrm{K}, \mathrm{Na}, \mathrm{Ni}, \mathrm{Zn}$ compared to that of 2011. Standard deviation of values of manganese and lead was the same in the two years while in the case of magnesium the values of 2011 showed greater standard deviation. This suggests that besides the effect of vintage, the effect of production area increases when the years show higher annual precipitation values regarding the nutrient quantity of grapes related to dry matter. 

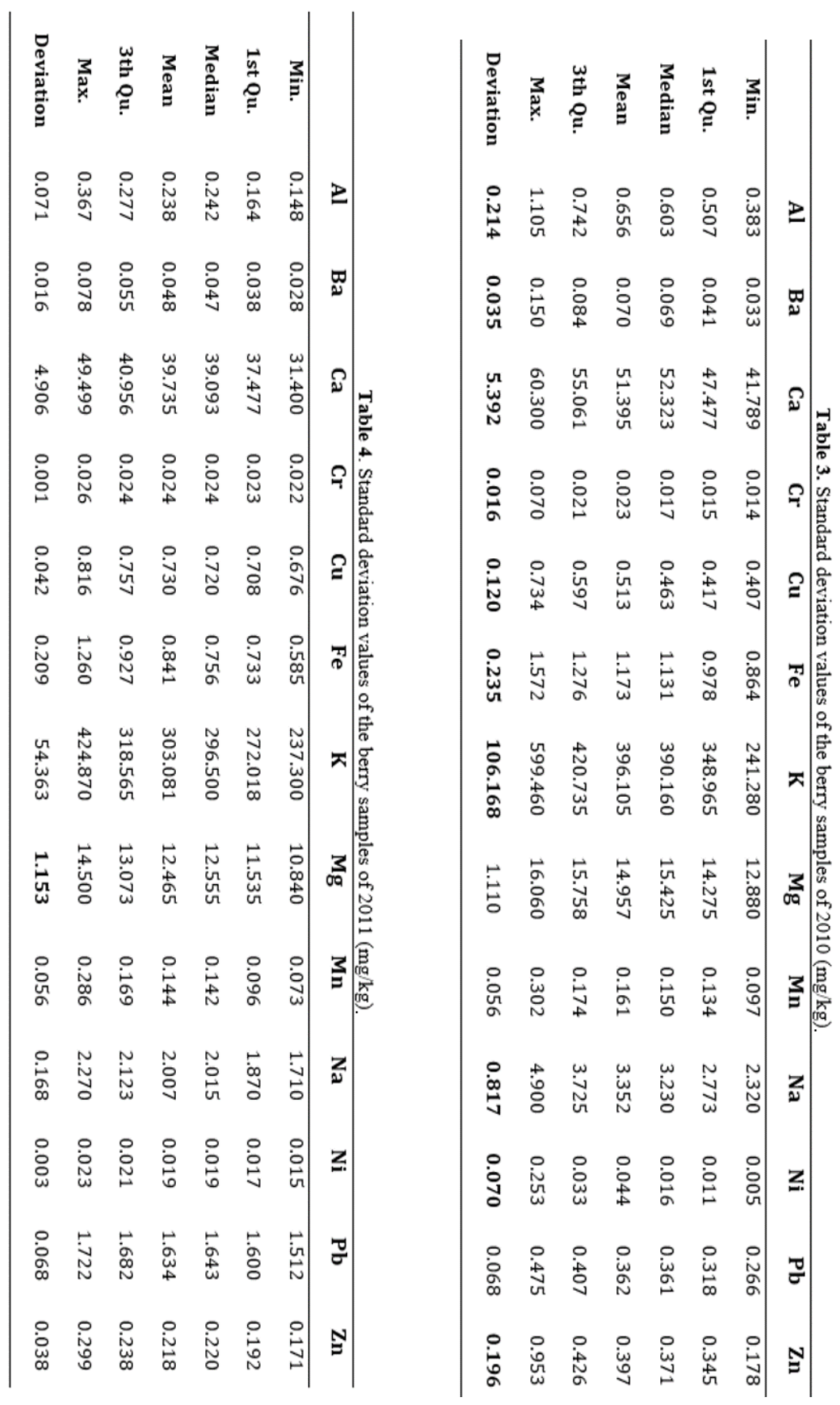
It is clear that according to literature references, the uptake of most elements - even if not all of them - varies from vintage to vintage depending primarily on the amount of annual precipitation.

\section{Impact of rainfall distribution over the year on elements uptake}

The second aspect of the present work was to study the variation of the quantity of different elements in the berries within two years with different amounts of precipitation.

Using the daily precipitation data of the plots equipped with a meteorological station, Spearman's rank correlation was performed in order to understand correlation with elemental concentration. In the course of the study, three periods were identified within the two studied years. Apart from annual precipitation data, the amount of precipitation in the growing season and also in the ripening periods was considered, as well (Table 5). As a result of different conditions of the two vintages, the length of the phenological phases and the date of harvest were different. The start of the growing season was taken as 1st April (bud break) while the starting date of ripening was determined to be 1st August. The end of the growing season and the ripening period are indicated by the date of harvest, 5th October in 2010 and 25th September in 2011.

Table 5. Amount of annual rainfall in 2010 and 2011, and also for the growing season and ripening $(\mathrm{mm})$.

\begin{tabular}{l|cccccc}
\hline $\begin{array}{l}\text { Production } \\
\text { area }\end{array}$ & $\begin{array}{c}\text { Total } \\
\text { for } \\
\text { 2010 }\end{array}$ & $\begin{array}{c}\text { Growing } \\
\text { season } \\
\text { in 2010 }\end{array}$ & $\begin{array}{c}\text { Ripening } \\
\text { period } \\
\text { in 2010 }\end{array}$ & $\begin{array}{c}\text { Total } \\
\text { for }\end{array}$ & $\begin{array}{c}\text { Growing } \\
\text { season } \\
\text { in 2011 }\end{array}$ & $\begin{array}{c}\text { Ripening } \\
\text { period in } \\
\text { 2011 }\end{array}$ \\
\hline KT & 1125.9 & 793.4 & 206 & 389.2 & 218.6 & 25.5 \\
SH & 949.9 & 693.5 & 204.7 & 329.6 & 185 & 16.9 \\
TB & 985.4 & 696.6 & 206 & 468.1 & 320.8 & 43.9 \\
SzH & 956.5 & 652.6 & 202.8 & 383.1 & 226.6 & 5.8 \\
JSz & 952.4 & 632.1 & 183.2 & 354 & 203.8 & 6 \\
NEA & 680.5 & 432.3 & 227.1 & 372.9 & 213.2 & 16.5 \\
NEF & 1120.4 & 805.4 & 252.9 & 359.8 & 186.4 & 7.9 \\
FD & 924.5 & 603.5 & 165.8 & 380.5 & 219.1 & 23.8 \\
VP & 1058.4 & 729.5 & 189.2 & 505.4 & 300.1 & 18.4 \\
\hline
\end{tabular}


In 2010 with relatively high amount of precipitation, the annual amount of it shows weak positive correlation with calcium and nickel, and weak negative correlation with copper. Considering the growing season, weak negative correlation was found with aluminium and copper while weak positive correlation was detected with nickel. Calcium, however, showed medium positive correlation ( $\mathrm{r}=0.567 ; \mathrm{p}=0.112)$. During ripening the amount of precipitation showed medium positive correlation with calcium $(\mathrm{r}=0.770 ; \mathrm{p}=0.015)$, sodium $(\mathrm{r}=0.603 ; \mathrm{p}=0.086)$ and lead $(\mathrm{r}=-0.31$; $\mathrm{p}=0.025$ ) while with iron and zinc weak positive, with barium and chromium weak negative correlations were found (Table 6).

In the dry year of 2011, the total amount of precipitation showed significant correlation with chromium $(\mathrm{r}=-0.767 ; \mathrm{p}=0.016)$ and copper $(\mathrm{r}=-0.720 ; \mathrm{p}=0.029)$, and medium correlation with manganese $(r=-0.633 ; p=0.067)$. Studying the growing season, significant correlation was found only with copper $(r=-0.703$; $\mathrm{p}=0.035)$, while medium correlation was detected with chromium $(\mathrm{r}=-0.575 ; \mathrm{p}=0.105)$ and manganese ( $\mathrm{r}=-0.567 ; \mathrm{p}=0.112)$. In contrast, in the ripening period significant correlation was found only with aluminium $(\mathrm{r}=0.750 ; \mathrm{p}=0.20)$, while weak correlation was detected with calcium, copper, manganese and zinc (Table 7).

The amounts of precipitation showed different correlations with different metals in the different studied periods in the two studied years. This enables to draw the conclusion that metal intake and accumulation are much more dependent on the amount of precipitation in the given year than on the distribution of precipitation in time. 


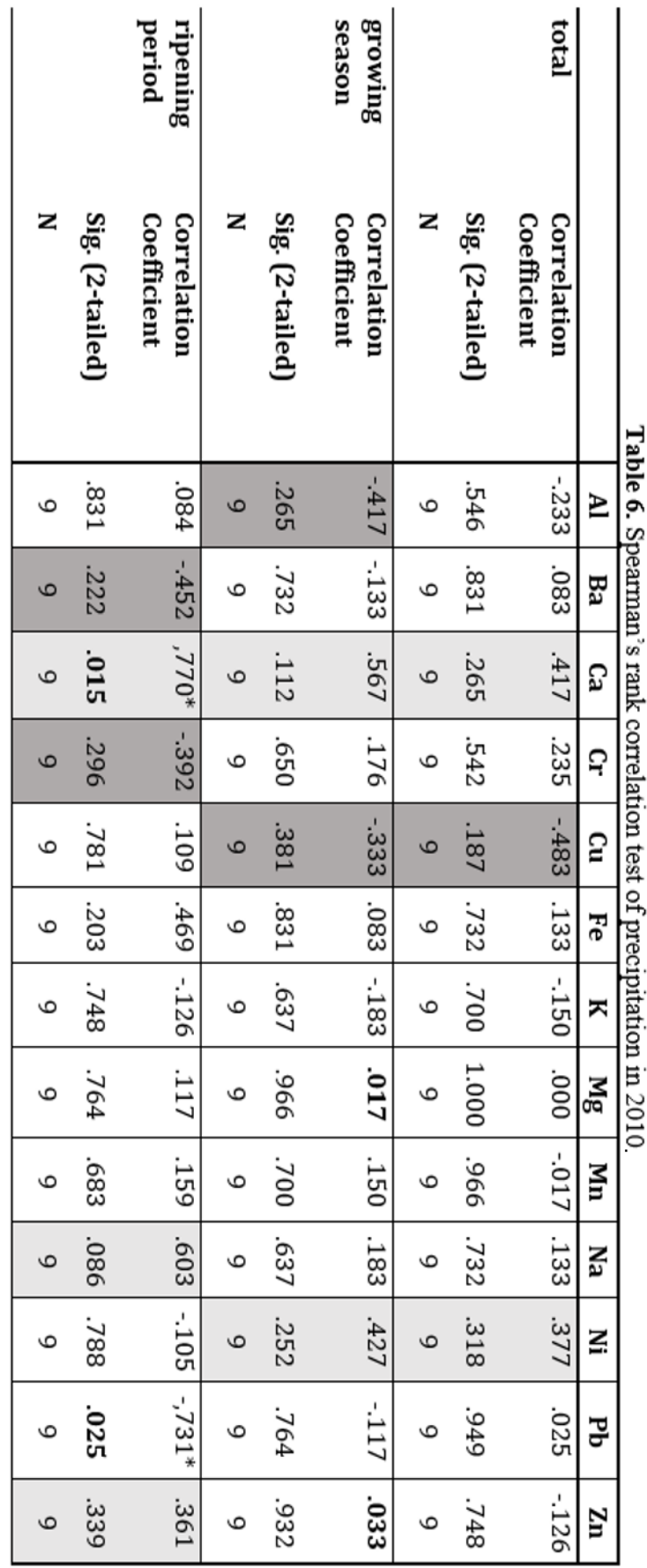




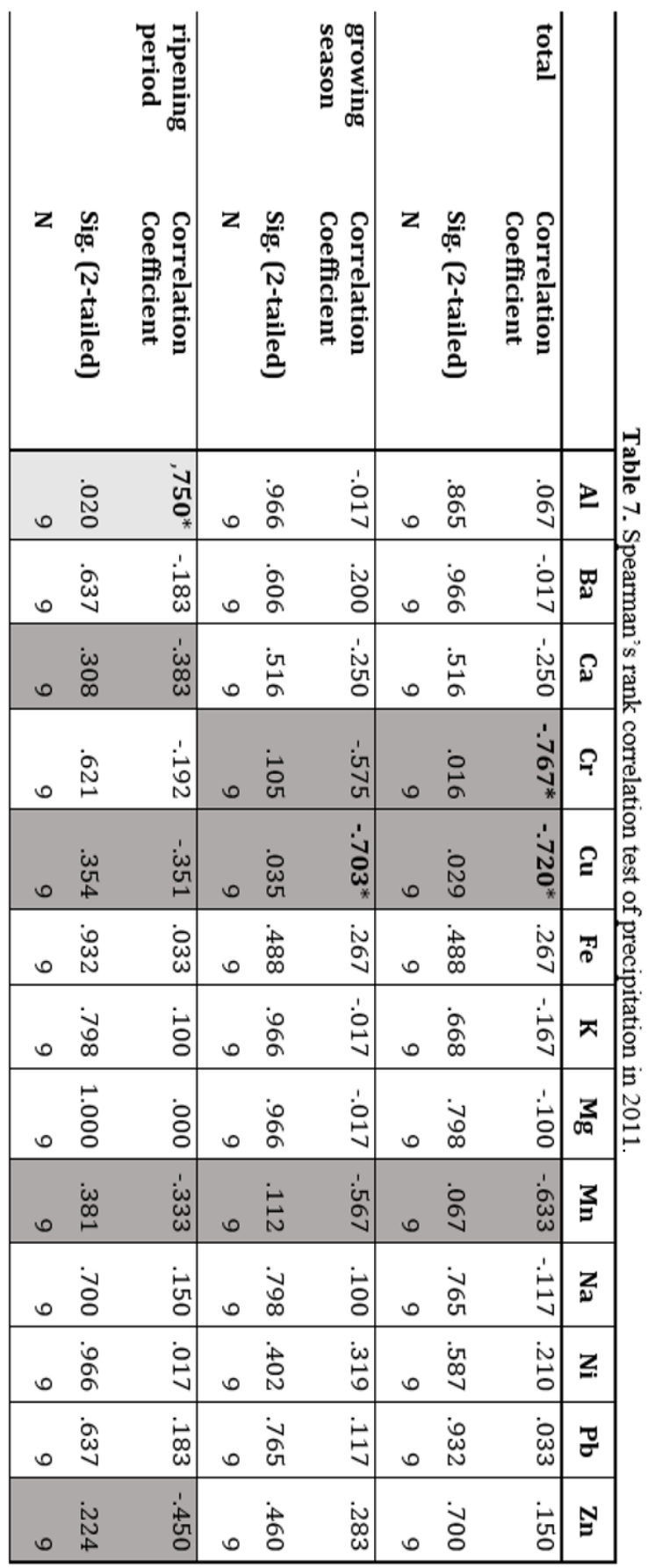




\section{CONCLUSIONS}

The effects of vintage were studied in two years (2010 and 2011) with contrasting climatic conditions. The results supported of preliminary hypotheses, that precipitation can significantly influence on the quantity of elements taken up by grapevine. Statistical analyses revealed that the effect of the production area is more characteristic in years with more precipitation (2010 in this case) regarding the elemental content related to dry matter content of grape berries. At the same time, no significant correlation was found between the uptake of certain elements and the amount of precipitation measured in the growing season and also in the ripening periods. This suggests that the intake and accumulation of the studied elements are much more dependent on the precipitation in a certain year than on the distribution of precipitation in time.

Acknowledgements - Supported by the ÚNKP-17-4 New National Excellence Program of the Ministry of Human Capacities.

\section{REFERENCES}

Alloway, B.J. (2012). Sources of Heavy Metals and Metalloids in Soils. In: AllowaY, B.J., ed., Heavy Metals in Soils. Trace Metals and Metalloids in Soils and Their Bioavailability, Environmental Pollution, Vol. 22, Springer, Dordrecht, pp. 1150. https://doi.org/10.1007/978-94-007-4470-7_2

De Andres-De Prado, R., Yuste Rojas, M., Sort, X., Andres lacueva, C., Torres, M. \& LAMUELA RAVENTOS, R.M. (2007). Effect of soil type on wines produced from Vitis vinifera L cv. Grenache in commercial vineyards. Journal of Agricultural and Food Chemistry 55(3): 779-786. https://doi.org/10.1021/jf062446q

BÁlo, B., Szilágyi, Z., SzÛ́cs, E., Marschall, M., Simon, Z. \& Zsófi, Zs. (2010). Tools for terroir classification for the grape variety Kékfrankos. In: ToMASI, D. (ed.) 8th International Terroir Congress, Soave, Italy, pp. 159-165.

Bartholy, J. \& Pongrácz, R. (2010). Analysis of precipitation conditions for the Carpathian Basin based on extreme indices in the 20th century and climate simulations for 2050 and 2100. Physics and Chemistry of the Earth, Parts $A / B / C$ 35(1-2): 43-51. https://doi.org/10.1016/j.pce.2010.03.011

Biró, B. (2015). The soil: Similar and distinct soil characteristics. In: BISZTRAY, Gy. D. \& Bodon P. (eds.): Wine terroirs and grape cultivars in Hungary. Budapesti Corvinus Egyetem, Budapest, pp. 14-18.

BRAmLEY, R.G.V., OUZMAN, J. \& BoSs, P.K. (2011). Variation in vine vigour, grape yield and vineyard soils and topography as indicators of variation in the chemical composition of grapes, wine and wine sensory attributes. Australian Journal of 
NAGY et al. (2018): Interrelation among precipitation and element-content in different terroirs

Grape and Wine Research 17: 217-229. https://doi.org/10.1111/j.17550238.2011.00136.x

Brancadoro, L., Valentini, L. \& Reina, A. (1995). Rootstock effect on potassium content of grapevine. ISHS Acta Horticulturae 383: 115-124. https://doi.org/10.17660/ActaHortic.1995.383.13

Brun, L.A., Maillet, J., Richarte, J., Herrmann, P. \& Remy, J.C. (1998). Relationships between extractable copper, soil properties and copper uptake by wild plants in vineyard soils. Environmental Pollution 102(2-3): 151-161. https://doi.org/10.1016/S0269-7491(98)00120-1

Candolfi-Vasconcelos, M.C., CASTAgnoli, S. \& BAHAM, J. (1997). Grape rootstocks and nutrient uptake efficiency. Proceedings of the Oregon Horticultiral Society 88: 221-228.

Coipel, J., Rodriguez Lovelle, B., SipP, C. \& Van Leeuwen, C. (2006). “Terroir” effect, as a result of environmental stress, depends more on soil depth than on soil type (Vitis vinifera L. cv. Grenache noir, Cotes du Rhone, France 2000). International Journal of Vine and Wine Sciences 40(4): 177-185. https://doi.org/10.20870/oeno-one.2006.40.4.867

Cus, F. (2004). The effect of different scion/rootstock combinations on yield properties of cv. Cabernet sauvignon. Acta Agriculturae Slovenica 83(1): 6371.

Deluisa, A., Giandon, P., Aicner, M., Bortolami, P., Bruna, L., Lupetti, A., Nardelli, F. \& STRINGALI, G. (1996). Copper pollution in Italian vineyard soils. Communications in Soil Science and Plant Analysis 27(5-8): 1537-1548. https://doi.org/10.1080/00103629609369651

DraPpiER, J., ThiBon, C., RABOT, A. \& GENY-Denis, L. (2017). Relationship between wine composition and temperature: Impact on Bordeaux wine typicity in the context of global warming - Review. Critical Reviews in Food Science and Nutrition 117. https://doi.org/10.1080/10408398.2017.1355776

GLAdSTONES, J. (1992). Viticulture and environment. Winetitles Publishers, Adelaide, $310 \mathrm{pp}$.

Hunter, J.J. \& Bonnardot, V. (2011). Suitability of Some Climatic Parameters for Grapevine Cultivation in South Africa, with Focus on Key Physiological Processes. South African Journal of Enology and Viticulture 32(1): 137-154. https://doi.org/10.21548/32-1-1374

Kocsis, L., Lehoczky, É., KereszTes, Z., Angyal, M. \& Walker, M.A. (2001). Grape Rootstock - Scion Combination Effects on Leaf Nutrient Status and Yield Under Drought Condition in Hungary. ASEV 52nd Annual Meeting, San Diego, California, USA, 21 pp.

Pepi, S., Sansone, L., Chicca, M., Marrocchino, E. \& Vaccaro, C. (2016). Distribution of rare earth elements in soil and grape berries of Vitis vinifera cv. Glera. Environmental. Monitoring and Assessment 188: 477-486. https://doi.org/10.1007/s10661-016-5490-1

Soriano, A., Pallarés, S., Pardo, F., Vicente, A.B., Sanfeliu, T. \& Bech, J. (2012). Deposition of heavy metals from particulate settleable matter in soils of an industrialised area. Journal of Geochemical Exploration 113: 36-44. https://doi.org/10.1016/j.gexplo.2011.03.006

SwinchatT, J. (2006). Soil or geology? And what's the difference? Some observations from the New World. VI. International Terroir Congress, pp. 128-132. 
Webb, M.A., Cavaletto, J.M. \& Carpita, N.C., Lopez, L.E. \& ARnotT, H.J. (1995). The intravacuolar organic matrix associated with calcium-oxalate crystals in leaves of Vitis. The Plant Journal 7(4): 633-648. https://doi.org/10.1046/j.1365313X.1995.7040633.X

WENG, H.X., ZhANG, X.M., CHEN, X.H. \& WU, N.Y. (2003). The stability of the relative content ratios of $\mathrm{Cu}, \mathrm{Pb}$ and $\mathrm{Zn}$ in soils and sediments. Environmental Geology 45: 79-85. https://doi.org/10.1007/s00254-003-0859-1

(submitted: 16.05.2018, accepted: 13.09.2018) 